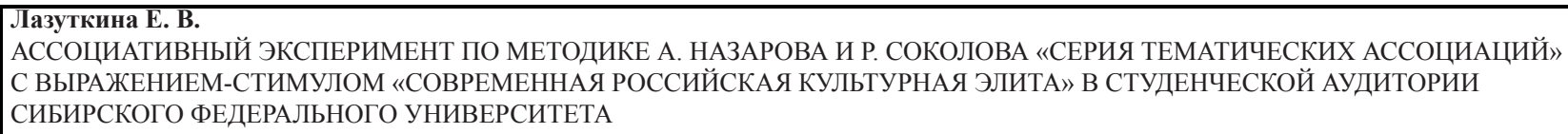

Лазуткина Е. В.

E. V. Lazutkina

АССОЦИАТИВНЫЙ ЭКСПЕРИМЕНТ ПО МЕТОДИКЕ А. НАЗАРОВА И Р. СОКОЛОВА

«СЕРИЯ ТЕМАТИЧЕСКИХ АССОЦИАЦИЙ» С ВЫРАЖЕНИЕМ-СТИМУЛОМ

«СОВРЕМЕННАЯ РОССИЙСКАЯ КУЛЬТУРНАЯ ЭЛИТА» В СТУДЕНЧЕСКОЙ

АУДИТОРИИ СИБИРСКОГО ФЕДЕРАЛЬНОГО УНИВЕРСИТЕТА

\title{
ASSOCIATIVE EXPERIMENT BY A. NAZAROV AND R. SOKOLOV'S PROCEDURE "SERIES OF THEMATIC ASSOCIATIONS" WITH THE STIMULUS "CONTEMPORARY RUSSIAN CULTURAL ELITE” AMONG STUDENTS OF SIBERIAN FEDEAL UNIVERSITY
}

Лазуткина Елена Владимировна - старший преподаватель кафедры иностранных языков для гуманитарных направлений Института филологии и языковой коммуникации Сибирского федерального университета (Россия, г. Красноярск). E-mail: helena120@mail.ru.

Ms. Elena V. Lazutkina - senior lecturer of Department of Foreign Languages for Humanities, Institute of Philology and Language Communication, Siberian Federal University (Russia, Krasnoyarsk). E-mail: helenal20@mail.ru.

Аннотация. В данной статье исследуется категория современной российской культурной элиты в общественном мнении студентов Сибирского федерального университета в рамках ассоциативного эксперимента по методике А. Назарова и Р. Соколова. В результате исследования получены ответы ста трех студентов и сведены к четырнадцати категориям ассоциатов. Разработан коллективный семантический спектр ответов, а также представлена таблица четырнадцати основных ассоциатов, проанализированы особенности ответов в связи с основными направлениями подготовки студентов. Полученные выводы могут помочь в коррекции образовательного и воспитательного процесса студентов.

Summary. The article deals with the concept of contemporary Russian cultural elite as a phenomenon of public opinion of the students of Siberian Federal University in the frame of A. Nazarov and R. Sokolov's associative experiment. As a result of our research we collected a hundred and three students' answers and reduced them to fourteen categories of associates. We developed a diagram of a collective semantic spectrum of thematic associations and a table of eleven major associates and analysed individualities of the answers of students majoring in different subjects. Conclusions can help with the correction of students' educational process.

Ключевые слова: современная российская культурная элита, ассоциативный эксперимент, ассоциат, студенты, общественное мнение.

Key words: contemporary Russian cultural elite, associative experiment, associate, students, public opinion.

УДК 008:378

В последнее время одним из перспективных направлений исследований социальных феноменов стал ассоциативный эксперимент. Он интересует нас с точки зрения отражения в теории культуры такого явления, как понятие современной российской культурной элиты.

Ассоциативный эксперимент как метод исследования пережил долго господствующую теорию ассоцианизма и применяется сейчас также и в психолингвистике, межкультурных исследованиях и других сферах. А. И. Назаров и Р. В. Соколов отметили: «... ассоциация - это не изначальный и не единственный механизм формирования и функционирования психических явлений, как это полагали классики ассоцианизма, а одна из конечных или промежуточных форм их протекания, сложившаяся в составе целостной предметной деятельности индивида. ... ассоциации следствие образованности, а не ее причина» $[4,126]$.

Ассоциативный эксперимент успешно применяется для диагностики знаний студентов или школьников в процессе обучения. Американские психологи разработали ассоциативный тест [6], в котором обучающимся предлагают список понятий по изучаемой теме, и они должны ответить 
на них соответствующим словом или короткой фразой. Степень их релевантности определяется четырехбалльной шкалой. Эти ответы являются воспринимаемым признаком того внутреннего содержания, которое присутствует в памяти диагностируемого.

В современных культурных исследованиях активно применяется метод ассоциативного эксперимента, который имеет давнюю укорененность в гуманитарном и социальном познании. Он позволяет на основе анализа сведений опытного знания отдельных индивидуумов делать обобщающие выводы о понимании содержания той или иной культурной реалии в обществе в целом [см. прим. 1, 2]. Ассоциативный эксперимент делает возможным выявить особенности понимания современной российской культурной элиты у молодежи - студентов Сибирского федерального университета, изучить вербальное выражение современного представления этого феномена.

Ассоциативный эксперимент не раз использовался для сбора и анализа эмпирического материала как часть диссертационных и других исследований в Сибирском федеральном университете. Так, А. А. Семенова в диссертационной работе «Модификации древнерусского концепта “государство” в российской культуре XXI века» посвятила третий параграф анализу результатов ассоциативного эксперимента на тему «государство», что позволило сделать практические выводы о том, через призму каких понятий молодежь в своем сознании воспринимает данный концепт, и что прежде всего стоит за этим словом для человека русской культуры [5]. Н. М. Либакова в диссертации «Модификации гендерных образов в российской культуре конца XIX - начала XXI веков» провела исследование тендерных представлений в современной культуре посредством ассоциативного эксперимента [3].

В августе 2015 г. Н. П. Копцева и К. В. Резникова опубликовали статью «Современная война как культурный феномен. Представили результаты ассоциативного эксперимента с ассоциатом “современная война"» и сделали важные культурологические выводы о коллективном восприятии современной войны в молодежной студенческой среде студентов Сибирского федерального университета [1].

Для проведения ассоциативного эксперимента была сделана определенная выборка из среды студентов, что согласуется с исследованиями отечественных и западных специалистов, отмечающих тот факт, что студенты, представляя собой весьма разнообразную социальную общность, выступают достаточно идеализированным объектом при проведении культурологических исследований [см. прим. 3].

Таким образом, применение ассоциативного эксперимента для культурологических исследований имеет определенную традицию и зарекомендовало себя положительно, поскольку предоставляет для данного анализа материал, связанный с актуальным содержанием тех или иных значимых понятий. Далее будут представлены результаты второго ассоциативного эксперимента со словосочетанием-стимулом «современная российская культурная элита» среди студентов СФУ, который следует за проведенным нами ранее ассоциативным экспериментом со словом-стимулом «элита» [1]. В эксперименте принимали участие студенты I-IV курсов различных институтов Сибирского федерального университета в возрасте от 17 до 23 лет, для которых русский язык является родным.

Респонденты направления «Философия» (13 человек) представили следующие ассоциаты, связанные с данным понятием (см. табл. 1):

\begin{tabular}{||l|l|l|l|}
\multicolumn{1}{|c|}{ Таблица 1 } \\
Далай-лама & Музеи & Книги & Скрипка \\
Духовно развитая часть & Театр 2 & Балет & Кинематограф \\
общества & Филармония & Актеры 2 и режиссеры & Культурно-духовная среда \\
Писатель 2 & Интеллигенция & Религия & Санкт-Петербург 2 \\
Культурно воспитанные & Эстеты & Ф. Бондарчук 2 & Музыка \\
люди & Мыслитель & Н. Михалков & П. Тодоровский \\
Интеллект & патриарх Кирилл & & \\
\hline \multicolumn{2}{|l}{} \\
\hline
\end{tabular}




\begin{tabular}{|c|c|c|c|}
\hline $\begin{array}{l}\text { ЛазУТКИНа Е. В. } \\
\text { АССОЦИАТИВНЫЙ ЭКСПЕРИМ } \\
\text { С ВЫРАЖЕНИЕМ-СТИМУЛОМ } \\
\text { СИБИРСКОГО ФЕДЕРАЛЬНОГО }\end{array}$ & $\begin{array}{l}\text { НТ ПО МЕТОДИК } \\
\text { СОВРЕМЕННАЯ Р } \\
\text { /НИВЕРСИТЕТА }\end{array}$ & $\begin{array}{l}\text { ВА И Р. СОКОЛОВА } \\
\text { КУЛЬТУРНАЯ ЭЛИ }\end{array}$ & $\begin{array}{l}\text { ІАТИЧЕСКИХ АССОЦИАЦИЙ» } \\
\text { НЧЕСКОЙ АУДИТОРИИ }\end{array}$ \\
\hline $\begin{array}{r}\text { Респонденты-сту } \\
\text { циации, связанные с поң }\end{array}$ & $\begin{array}{l}\text { енты направл } \\
\text { нтием «соврел }\end{array}$ & $\begin{array}{l}\text { стория» (22 чел } \\
\text { сссийская культ }\end{array}$ & $\begin{array}{l}\text { казали на следующие ассо- } \\
\text { Іта» (см. табл. 2): }\end{array}$ \\
\hline & & & Таблица 2 \\
\hline $\begin{array}{l}\text { Представитель элиты - } \\
\text { женщина рассуждает о } \\
\text { роли человека в судьбе } \\
\text { Отечества } \\
\text { Люди с высоким уров- } \\
\text { нем образования } \\
\text { Поэзия } \\
\text { В. Путин } 2 \\
\text { М. Боярский } \\
\text { Г. Лепс } 2\end{array}$ & $\begin{array}{l}\text { Поэты } 2 \\
\text { Церковь } 2 \\
\text { Религия } 4 \\
\text { Музеи } 2 \\
\text { Музыка } 3 \\
\text { Библиотеки } \\
\text { Телевидение } \\
\text { Роскошь } \\
\text { Художники } \\
\text { Писатели } \\
\text { Н. Михалков }\end{array}$ & $\begin{array}{l}\text { Образование } 2 \\
\text { Театры } 3 \\
\text { Литература } 5 \\
\text { Просвещение } \\
\text { Союз писателей } \\
\text { Книги } 5 \\
\text { Аристократия } 3 \\
\text { Эрудиция } \\
\text { Валерия } \\
\text { И. Резник } \\
\text { А. Градский }\end{array}$ & $\begin{array}{l}\text { Мыслители } \\
\text { Сильные духом люди } \\
\text { Наука } \\
\text { Воспитание } \\
\text { Живопись } \\
\text { Искусство } \\
\text { О. Байрон } \\
\text { С. Лавров } \\
\text { Е. Понасенков } \\
\text { В. Карпин } \\
\text { Ф. Бондарчук }\end{array}$ \\
\hline
\end{tabular}

Респонденты-студенты направления «Документоведение и архивоведение» (20 человек) предложили следующие ассоциации на понятие «современная культурная элита» (см. табл. 3):

\begin{tabular}{||l|l|l|l||}
\hline Певцы & Театры 4 & Артисты & Школа \\
Преподаватель & Поэты & Места отдыха & Опера \\
Церковь & Парки & И. Кобзон 3 & Иковное песнопение 2 \\
Муза & Интеллигенция 2 & Н. Михалков 3 2 \\
Туризм & Кинотеатры & О. Газманов & Храмостроительство \\
Д. Донцова & Красная площадь & С. Безруков 2 & Молитва \\
патриарх Кирилл 4 & В. Путин & А. Малахов & Паломничество \\
Д. Нагиев 2 & Ф. Бондарчук 5 & А. Градский 2 & \\
Л. Якубович & Конгар-оол Ондар & &
\end{tabular}

Студенты направления «Прикладная информатика» (26 респондентов) отметили следующие ассоциаты (см. табл. 4):

\begin{tabular}{|c|c|c|c|}
\hline $\begin{array}{l}\text { Д. Хворостовский } 2 \\
\text { Н. Пиков } \\
\text { Ф. Бондарчук } \\
\text { Ю. Шевчук } \\
\text { Г. Сукачев } \\
\text { И. Найшуллер } \\
\text { С. Пахомов } \\
\text { А. Вассерман } \\
\text { Поэзия } \\
\text { Традиции } \\
\text { Ученые } \\
\text { Актеры } \\
\text { Художники } \\
\text { Музеи } \\
\text { Воспитание }\end{array}$ & $\begin{array}{l}\text { М. Кравец } \\
\text { Патриарх Кирилл } \\
\text { С. Лукъяненко } \\
\text { Г. Харламов } \\
\text { А. Замараев } \\
\text { В. Путин } 2 \\
\text { Хор Турецкого } \\
\text { С. Шнуров } \\
\text { Интеллигенция } \\
\text { Честность } \\
\text { Доброта } \\
\text { Литераторы } \\
\text { Санкт-Петербург } \\
\text { Эстетика } \\
\text { Гр. Ситеп }\end{array}$ & $\begin{array}{l}\text { И. Охлобыстин } \\
\text { М. Задорнов } 2 \\
\text { И. Дапкунайте } \\
\text { Д. Козловский } \\
\text { Ч. Хаматова } \\
\text { П. Шаляпин } \\
\text { Живопись } \\
\text { Меценаты } \\
\text { Изысканность } \\
\text { Культура } \\
\text { Духовность } \\
\text { Оркестры } \\
\text { Народ } \\
\text { Театры } 5\end{array}$ & $\begin{array}{l}\text { Н. Михалков } 3 \\
\text { И. Кобзон } \\
\text { В. Демчог } 3 \\
\text { Паша } 183 \\
\text { С. Лавров } \\
\text { Братья Стругацкие } \\
\text { Церковь } 2 \\
\text { Искусство } 2 \\
\text { Музыка } \\
\text { Образованность } 2 \\
\text { Английский язык } \\
\text { Философы } \\
\text { Искусствоведы } \\
\text { История России }\end{array}$ \\
\hline
\end{tabular}




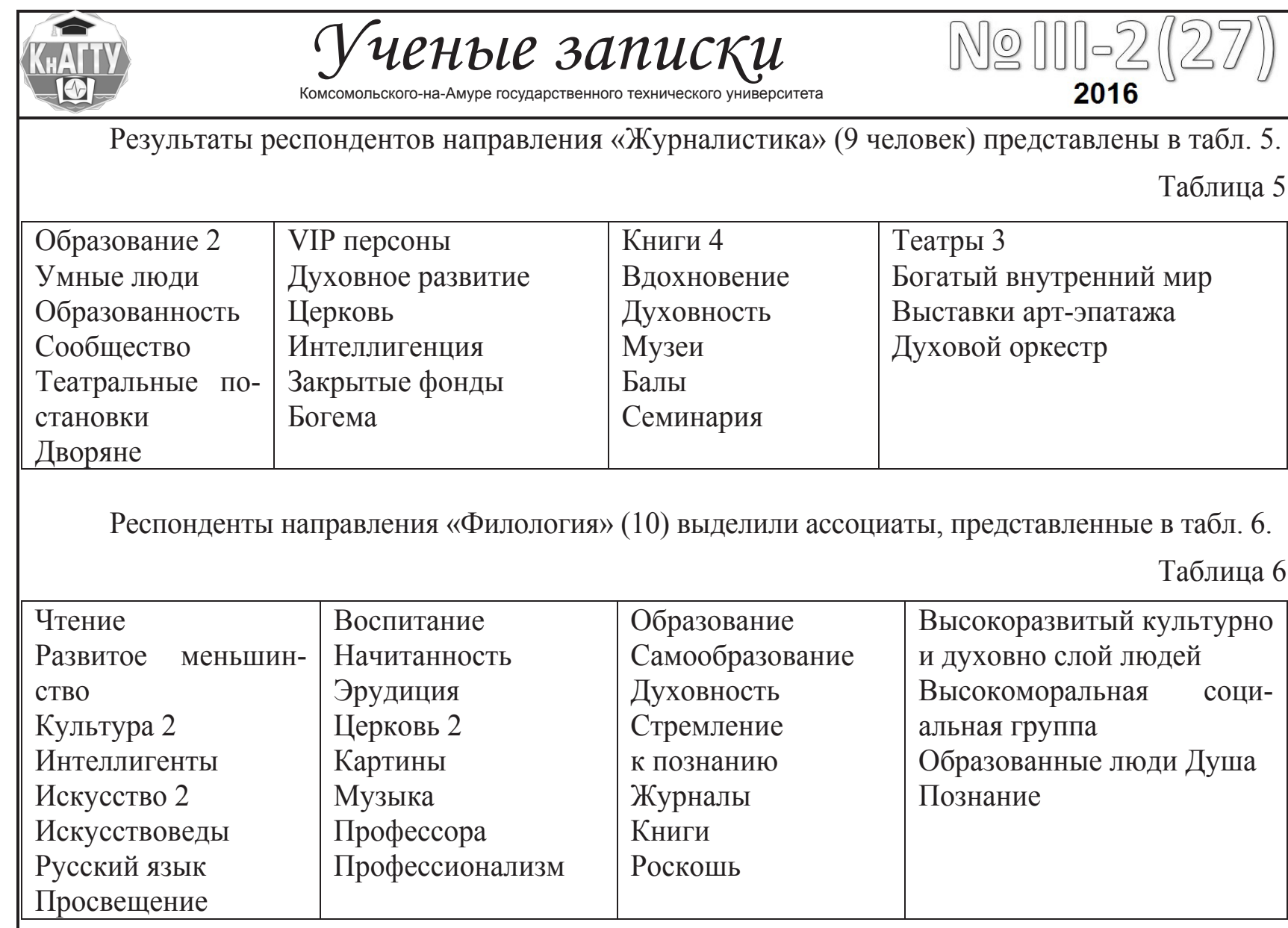

Студентка направления «Социология» назвала ассоциаты, представленные в табл. 7.

Таблица 7

\begin{tabular}{|c|c|c|}
\hline Д. Хворостовский & А. Пугачева & М. Боярский \\
\hline \multicolumn{3}{|c|}{$\begin{array}{l}\text { Студентка направления «Менеджмент социально-культурной деятельности» зафиксировала } \\
\text { ассоциаты, представленные в табл. } 8 .\end{array}$} \\
\hline & & Таблица 8 \\
\hline В. Путин & Пелагея & С. Безруков \\
\hline
\end{tabular}

Студентка направления «Медицина - лечебное дело» предложила ассоциаты, отраженные в табл. 9.

Таблица 9

\begin{tabular}{|l|l|l|}
\hline Ф. Бондарчук & А. Чапман & Мот \\
\hline
\end{tabular}

В исследовании принимали участие 103 студента различных направлений, в основном из Гуманитарного института, Института филологии и языковой коммуникации и Юридического института СФУ. Всего из этих анкет получены 288 ассоциата, так как некоторые студенты написали всего один или два ассоциата, и некоторые ассоциаты не соответствовали теме. Исследование было проведено в октябре 2015 года.

Объединим отдельные ассоциаты в более крупные смысловые группы, охватывающие наиболее часто встречающиеся ассоциаты. Наиболее популярным ассоциатом с концептом «современная российская культурная элита» является комплекс понятий, связанных с кинематографом. Это такие ассоциаты, как «актеры» (упоминаются 3 раза), «кинематограф» (1 раз), «киноте- 
Лазуткина Е. В.

АССОЦИАТИВНЫЙ ЭКСПЕРИМЕНТ ПО МЕТОДИКЕ А. НАЗАРОВА И Р. СОКОЛОВА СЕРИЯ ТЕМАТИЧЕСКИХ АССОЦИАЦИЙ» С ВЫРАЖЕНИЕМ-СТИМУЛОМ «СОВРЕМЕННАЯ РОССИЙСКАЯ КУЛЬТУРНАЯ ЭЛИТА» В СТУДЕНЧЕСКОЙ АУДИТОРИИ СИБИРСКОГО ФЕДЕРАЛЬНОГО УНИВЕРСИТЕТА

атры» (1 раз) и имена актеров и режиссеров (некоторые повторяются 34 раза). Всего эти ассоциаты упоминаются 39 раз.

Следующей большой группой ассоциатов выступают ассоциаты, связанные с музыкой (6 раз), оркестрами (2), певцами (1) и композиторами (24 раза упоминаются имена певцов, композиторов и название группы, некоторые повторяются). Эти ассоциаты всего были упомянуты 34 раза.

Ассоциаты, связанные с жанром поэзии и поэтами (5 раз), писателями (3 раза, имена писателей и публицистов - 6 раз), литературой вообще (5 раз), литераторами (1 раз), повторяются всего 20 раз. Близкими по значению ассоциатами является кластер «книги» (11), «чтение» (1), «начитанность» (1), библиотеки (1), что составляет 13 ассоциатов. Всего в этой группе 33 ассоциата.

Достаточно часто с названной темой студенты ассоциируют понятия «церковь» (9 раз), «религия» (5 раз) и все, что связано с ними (патриарх Кирилл», «иконопись» и другое - 14 раз). Они повторяются 28 раз.

Понятие «образование» и его релеванты повторяются 13 раз. Опять же, близкими по содержанию к этой группе оказываются ассоциаты, связанные с наукой (1), «профессора» (1), «ученые» (1), «преподаватель» (1 ра3), имя преподавателя - 1 раз, «просвещение» (1) и близкие к ним «интеллект», «интеллигенция» (4 раза). Всего в этой группе 23 ассоциата.

Концепт «театры» оказался довольно распространенным, всего 17 раз. Релевантные концепты, такие, как «балет» (1), «театральные постановки» (1), «опера» (1), «сцена» (1), «скрипка» (1), «филармония» (1) добавляют популярности этой группе. Всего 23 ассоциата.

Некоторые студенты ассоциируют понятие «современная российская культурная элита» с искусством (5), искусствоведами (2), живописью (1), художниками (2), картинами (1) и примыкающими к этой группе выставками арт-эпатажа (1), культурой (3), культурно воспитанными людьми (1), эстетикой (1), именем художника (1), упоминая ассоциаты данной сферы 18 раз.

Другие связывают этот концепт с духовностью и близкими ей понятиями («духовно развитая часть общества», «культурно-духовная среда», «душа», «богатый внутренний мир» и т. д.), упоминаемыми 8 раз.

Ряд респондентов связывает рассматриваемое понятие с телевидением (1) и личностями, связанными с телевидением (5), эти ассоциаты встречаются 6 раз.

Неоднократно понятие «современной российской культурной элиты» связывается с политическими деятелями - В. Путиным (6) и С. Лавровым (2) - всего 8 раз.

В особую группу выделим концепт «музеи», который используется 5 раз.

Некоторые обращают внимание на происхождение: это ассоциаты «аристократия» (3) и дворяне (1) - всего 4.

Другие ассоциируют рассматриваемое понятие с чем-то привилегированным, закрытым или с обществами, в которые трудно попасть («особые группы», «закрытые фонды», «Союз писателей», «развитое меньшинство») (4 раза).

Два студента считают русский и английский языки признаками современной российской культурной элиты.

Есть определения, которые раскрывают известные стороны понятия «современная российская культурная элита»; это: «представитель элиты - женщина рассуждает о роли человека в судьбе Отечества», «высокоморальная социальная группа» и «высокоразвитый культурно и духовно слой людей» (3 раза).

Представим диаграмму коллективного семантического спектра тематических ассоциаций по основным группам ассоциатов в связи с понятием «элита» (см. рис. 1). 


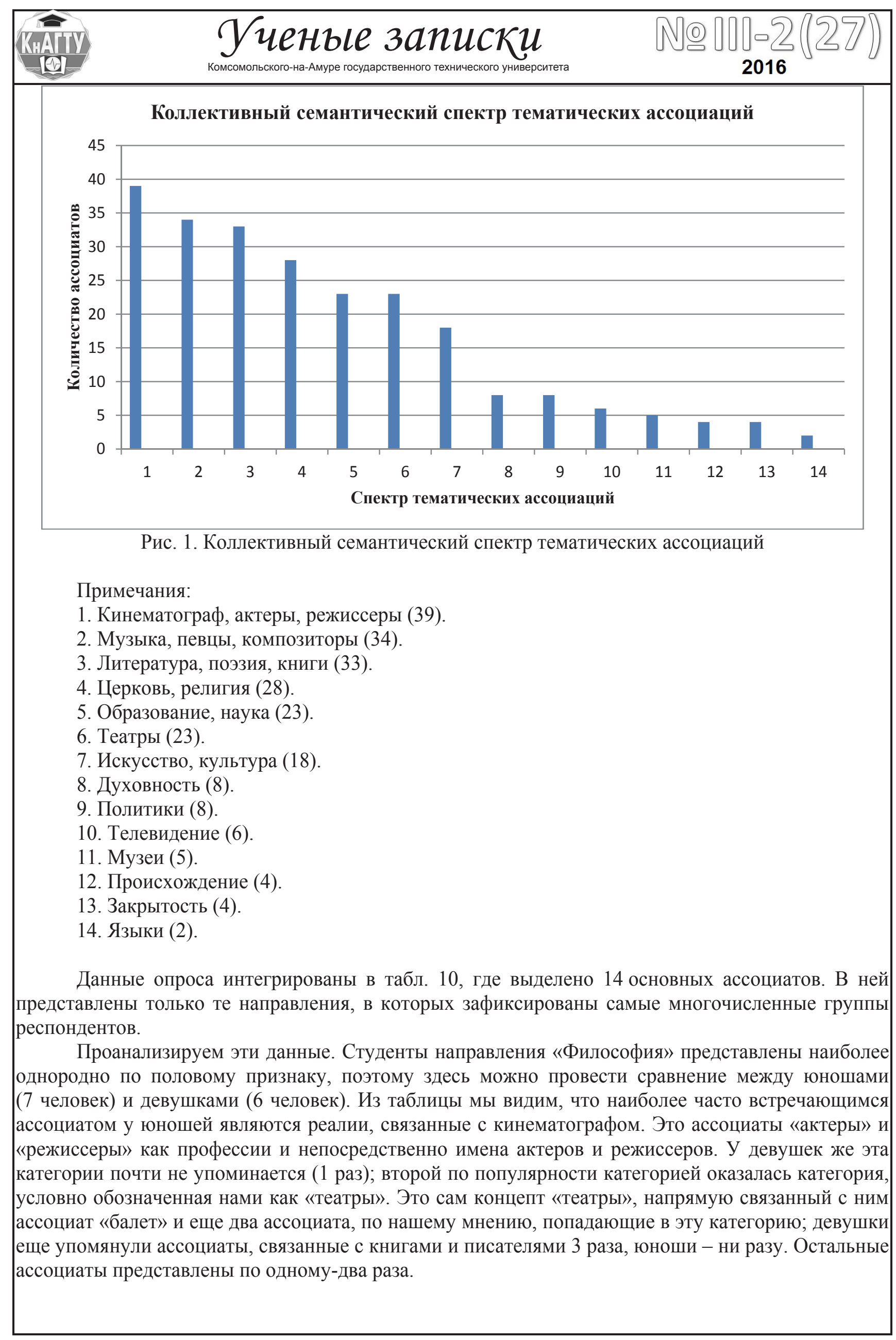




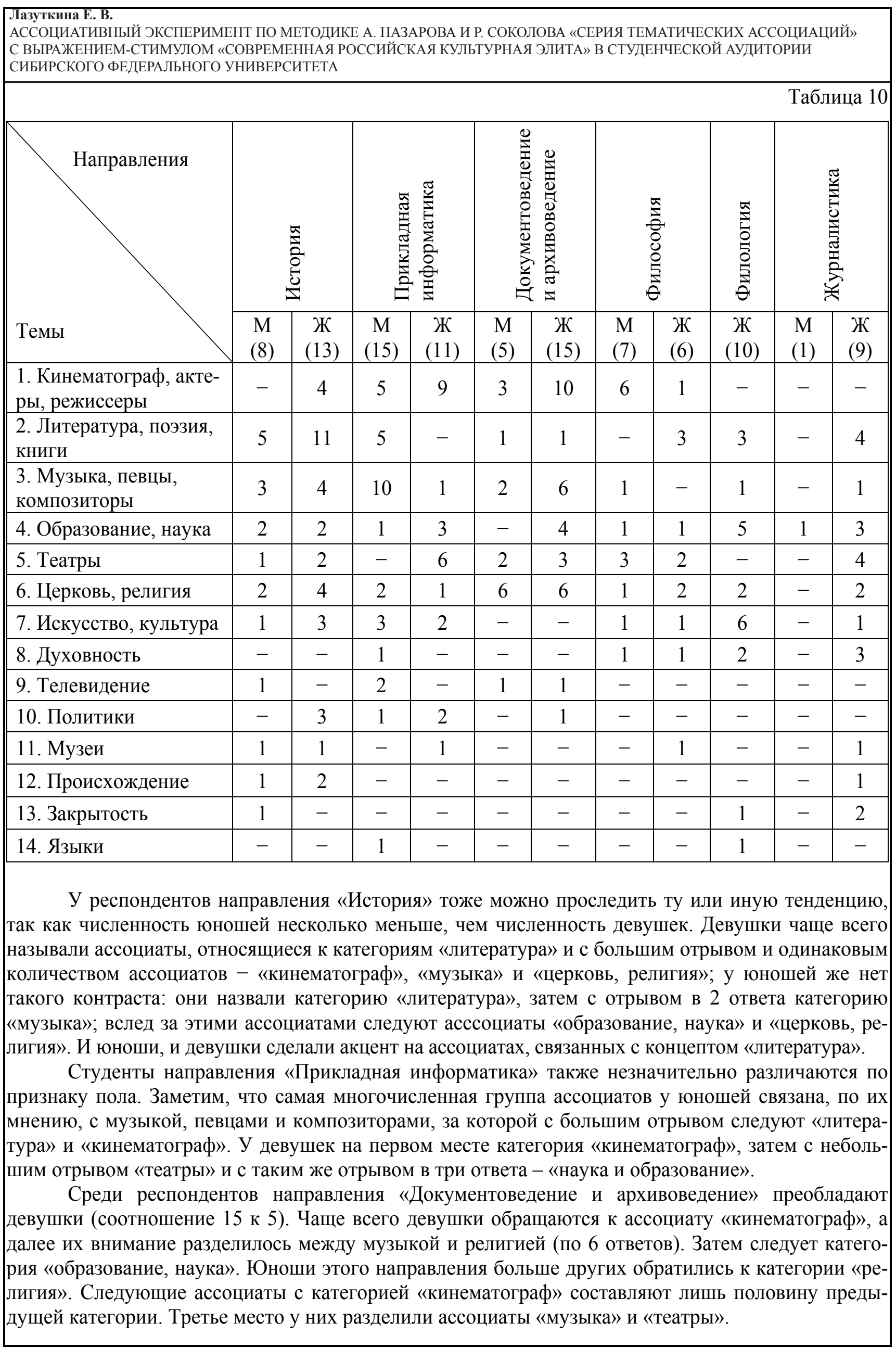


Все студенты направления «Филология», которые отмечали ассоциаты, являются девушками (10 человек). На первом месте у них ассоциат «искусство, культура», далее с разницей в один ответ - «образование, наука»; далее идет «литература».

У студентов направления «Журналистика» абсолютное большинство составляют девушки (9 к 1), поэтому не представляется возможным выявить какие-либо гендерные тенденции. В дополнение к этому единственный юноша из трех дал два ассоциата, которые не соответствовали заданной теме. Первое место девушки разделили между литературой и театрами, второе - между образованием и духовностью, поставив на третье религию и закрытость данной элиты; молодой человек отметил лишь образование.

Опираясь на статью А. И. Назарова и Р. В. Соколова, а именно на введенные ими категории ассоциатов, нам наиболее важно выделить содержание, состав элиты и ее свойства, поэтому мы возьмем только первые три категории, то есть ассоциаты, характеризующие структурный состав и содержание темы, ее свойства и внешние характеристики, и ассоциаты, имеющие близкое отношение к теме. На примере группы студентов направления «История» наглядно покажем, как можно присвоить номер ассоциатам в соответствии с тем, насколько они логически приближены к существенным признакам темы. Такие ассоциаты, как «люди с высоким уровнем образования», «просвещение», «сильные духом люди», «религия», конкретные фамилии и имена деятелей культуры репрезентируют место культурной элиты в обществе, поэтому мы их отнесем к первой категории. «Телевидение», «литература», «искусство», «театры» являются более внешними характеристиками данной элиты и соответствуют второй категории. Более удаленное отношение к элите имеют ассоциаты «представитель элиты - «женщина рассуждает о роли человека в судьбе Отечества», «роскошь», «аристократия», «эрудиция», «мыслители», связь которых с темой прослеживается лишь с помощью дополнительных звеньев; и в данных случаях можно говорить о специфике индивидуального опыта.

Сделаем выводы. Специфической формой отражения в истории и теории культуры такого социального феномена, как элита, является ассоциативный эксперимент. Как было указано, он был проведен в основном в трех институтах Сибирского федерального университета в октябре 2015 г. В нем приняли участие 124 студента; были проанализированы 103 анкеты.

Проведенный анализ ассоциатов по заданной теме выявил следующие особенности общественного восприятия феномена «современная российская культурная элита» в данной социальной группе респондентов. Выяснилось, что ассоциаты «кинематограф, актеры, режиссеры» значительно более распространены, чем все другие (39 ответов). Следом за ними следуют ассоциаты «музыка, певцы, композиторы» (34 ответа). Количественно близкими по массовому восприятию - отражению в понятиях - оказались «литература, поэзия, книги» (33 ответа), «церковь, религия» (28 ответов), «образование, наука» (23 ответа), «театры» (23 ответа) и «искусство, культура» (18 ответов). С большим отставанием далее следуют «духовность» (8), «политики» (8), «телевидение» (6), «музеи» (5), «происхождение» (4), «закрытость» (4) и «языки» (2).

В студенческой культурной сфере, учитывая ограниченную выборку респондентов, с российской культурной элитой в первую очередь связываются ассоциаты актеров и певцов. Поскольку ответы давали студенты, они, в силу своего положения в обществе и в системе образования, достаточно часто связывали элиту с ассоциатом «образование, наука». В целом ассоциаты «происхождение», «закрытость» этой группы, «языки», знание которых, видимо, необходимо рассматриваемой элите, - оказались на последних (12-14) местах.

Представляет интерес и разброс общественных мнений, ассоциатов среди ответов студентов в зависимости от направления обучения (рассмотрены шесть направлений) и от пола. Эти особенности зафиксированы выше.

Перейдем к практическим выводам. Если допустить, что данные ассоциаты отражают в известной степени достоверность реального положения и роли культурной элиты в российском обществе, то следует признать, что она не полностью соответствует стратегическим и тактическим целям и задачам трансформации России из развивающейся страны в современную развитую державу. 
Лазуткина Е. В.

АССОЦИАТИВНЫЙ ЭКСПЕРИМЕНТ ПО МЕТОДИКЕ А. НАЗАРОВА И Р. СОКОЛОВА СЕРИЯ ТЕМАТИЧЕСКИХ АССОЦИАЦИЙ» С ВЫРАЖЕНИЕМ-СТИМУЛОМ «СОВРЕМЕННАЯ РОССИЙСКАЯ КУЛЬТУРНАЯ ЭЛИТА» В СТУДЕНЧЕСКОЙ АУДИТОРИИ СИБИРСКОГО ФЕДЕРАЛЬНОГО УНИВЕРСИТЕТА

Современная российская культурная элита, как следует из вышеизложенного и что отражается в культурных представлениях - деятельности членов общества, в частности, на примере проанализированных ассоциатов, многопланова, многофункциональна и многолика. Вместе с тем она, как и все российское общество, все другие элиты, глубоко противоречива, нередко непоследовательна, порой аморфна. Например, известный специалист в области теорий цивилизаций Н. И. Лапин полагает, что элиты России, в том числе ее культурная элита, не сделали в настоящее время судьбоносный и необходимый выбор в пользу гуманистической модернизации и ее трех фундаментальных составляющих (жизнь человека, достоинство человека и ненасилие) $[2,12]$.

Ведущая роль в современной культурной элите принадлежит ее столичным деятелям благодаря СМИ и другим способам широкого воздействия на аудиторию (демонстрации кинофильмов, концертам, спектаклям, фестивалям и т. д.). Не случайно некоторые респонденты связывают свои ассоциаты с Москвой, столичной элитой и Санкт-Петербургом. Определенную роль в культурном развитии российского общества играют и региональные, местные культурные элиты, в частности, красноярская.

К позитивным сторонам рассматриваемой элиты мы относим защиту независимости России, ее единства, утверждение патриотизма, реализацию идеи «Бессмертного полка», содействие сотрудничеству народов страны, толерантности конфессий, развитие уважения к истории Отечества, традициям, миссии миролюбия и социальной справедливости на планете, отрицание двойных стандартов в международной жизни и в российском обществе, неприятие коррупции и другое.

К слабым сторонам российской культурной элиты мы относим коммерциализацию культуры, конкуренцию деятелей культуры, насаждение масс-культуры в обществе, либеральнозападную ориентацию части элиты в условиях идеологического противостояния, их индифферентное отношение к западным санкциям в отношении России в целом и ее отдельным деятелям культуры.

В ассоциатах респондентов эти противоречивые тенденции деятельности российской культурной элиты нашли свое определенное отражение как в ее позитивных чертах, так и в ее слабых сторонах.

Наиболее часто встречающиеся ассоциации к ассоциату «современная российская культурная элита» - это «кинематограф, актеры» и «музыка, певцы, композиторы». Коллективное восприятие современной российской культурной элиты в студенческой среде Сибирского федерального университета может быть экстраполировано на более широкие социальные слои молодежи и студенчества Российской Федерации. Результаты исследования могут быть применены при принятии политических и социальных решений, при планировании программ молодежной политики, патриотического воспитания, а также для адекватного восприятия молодежной и студенческой среды Красноярского края.

\section{ЛИТЕРАТУРА}

1. Копцева, Н. П. Современная война как культурный феномен. Результаты ассоциативного эксперимента c ассоциатом «современная война» (на материале исследований в студенческих группах Сибирского федерального университета) / Н. П. Копцева, К. В. Резникова // Журнал Сибирского федерального университета. Гуманитарные науки. - 2015. Т. 8. - № 8. - С. 1591-1610.

2. Лапин, Н. И. Человеческая цивилизация перед выбором конфигурации фундаментальных ценностей / Н. И. Лапин // Вопросы философии. - 2015. - № 4. - С. 3-15.

3. Либакова, Н. М. Модификация гендерных образов в российской культуре конца XIX - начала XXI веков: дис. ... канд. филос. наук: 24.00.01 / Либакова Наталья Михайловна. - Красноярск, 2011. - 155 с.

4. Назаров, А. И. Ассоциация и ассоциативный эксперимент: Разные судьбы / А. И. Назаров, Р.В. Соколов // Вопросы психологии. 2007. - № 4. - С. 125-138.

5. Семенова, А. А. Модификации древнерусского концепта «государство» в российской культуре XXI века: дис. ...канд. филос. наук: 24.00.01 / Семенова Александра Александровна. - Красноярск, 2009. - 198 с.

6. Lazutkina, Elena V. Social Consciousness and Public Opinion: Associative Experiment Among Students of SibFU. Journal of Siberian Federal University, 2015, 8 (vol. 8) - pp. 1855-1863. 
7. Verplanck, W. S. A Brief Introduction to the Word Associate Test. The Analysis of Verbal Behavior, 1992. V. 10. P. $97-123$.

\section{ПРИМЕЧАНИЯ}

1. Леонтьев, А. Н. Опыт структурного анализа цепных ассоциативных рядов: экспериментальное исследование / А. Н. Леонтьев // Избранные психологические произведения. Т. 2. - М.: Педагогика, 1983. - С. 50-71. 2. Палкин, А. Д. Ассоциативный эксперимент как способ кросс-культурного исследования образов сознания // Вопросы психологии. 2008. - № 4. - С. 81-89.

3. Русский ассоциативный словарь. Ассоциативный тезаурус современного русского языка. Т. 1. Кн. 1-2 Ю. Н. Караулов, Ю. А. Сорокин, Е. Ф. Тарасов, Н. В. Уфимцева. - М.: Помовский и партнеры, 1994. - 223 с. 